\title{
Differential nitric oxide synthesis and host apoptotic events correlate with bleaching susceptibility in reef corals
}

\author{
T. D. Hawkins $\cdot$ T. Krueger $\cdot$ S. Becker $\cdot$ \\ P. L. Fisher $\cdot$ S. K. Davy
}

Received: 26 September 2013/Accepted: 12 November 2013/Published online: 4 February 2014

(c) Springer-Verlag Berlin Heidelberg 2014

\begin{abstract}
Coral bleaching poses a threat to coral reefs worldwide. As a consequence of the temperature-induced breakdown in coral-dinoflagellate symbiosis, bleaching can have extensive effects on reef communities. However, our understanding of bleaching at a cellular level is limited, and this is particularly true regarding differential susceptibility among coral species. Recent work suggests that bleaching may represent a host innate immune-like response to symbiont dysfunction that involves synthesis of the signalling compound nitric oxide (NO) and the induction of host apoptotic-like cell death. In this study, we examined the activity of apoptosis-regulating enzymes alongside oxidised NO accumulation (a proxy for NO synthesis) in the reef corals Acropora millepora, Montipora digitata, and Pocillopora damicornis during experimental thermal stress. $P$. damicornis was the most sensitive species, suffering mortality (tissue sloughing) after 5 days at $33^{\circ} \mathrm{C}$ but non-lethal bleaching after 9 days at $31.5^{\circ} \mathrm{C}$. A. millepora bleached at $33{ }^{\circ} \mathrm{C}$ but remained structurally intact, while $M$. digitata showed little evidence of bleaching. P. damicornis and A. millepora both exhibited evidence of temperature-induced NO synthesis and, after 5 days of heating, levels of oxidised NO in both species were fivefold higher than in controls maintained at $28.5^{\circ} \mathrm{C}$. These responses preceded bleaching
\end{abstract}

Communicated by Biology Editor Dr. Anastazia Banaszak

Electronic supplementary material The online version of this article (doi:10.1007/s00338-013-1103-4) contains supplementary material, which is available to authorized users.

T. D. Hawkins - T. Krueger $\cdot$ S. Becker .

P. L. Fisher · S. K. Davy $(\square)$

School of Biological Sciences, Victoria University of

Wellington, PO Box 600, Wellington, New Zealand

e-mail: simon.davy@vuw.ac.nz by a number of days and may have occurred before symbiont dysfunction (measured as chlorophyll $a$ degradation and oxidised NO accumulation). In A. millepora, apparent NO synthesis correlated with the induction of host apoptotic-like pathways, while in $P$. damicornis, the upregulation of apoptotic pathways occurred later. No evidence of elevated NO production or apoptosis was observed in $M$. digitata at $33{ }^{\circ} \mathrm{C}$ and baseline activity of apoptosis-regulating enzymes was negligible in this species. These findings provide important physiological data in the context of the responses of corals to global change and suggest that early events in the host may be important in the collapse of the coral-dinoflagellate symbiosis.

Keywords Thermal stress - Climate change . Symbiodinium · Cnidarian-dinoflagellate symbiosis

\section{Introduction}

Tropical coral reefs face an uncertain future in a changing climate (van Hooidonk et al. 2013), and oceanic warming is already leading to declining reef health (Mydlarz et al. 2010). Reef corals are a complex symbiosis between a scleractinian host, photosynthetic dinoflagellate symbionts of the genus Symbiodinium, and a diverse microbial community (Muscatine and Porter 1977). The provision of organic carbon by the Symbiodinium cells enables corals to grow rapidly in nutrient-poor tropical seawater (Muscatine and Porter 1977). However, reef corals live close to their upper thermal thresholds and warming of only a few degrees can destabilise this symbiosis (Hoegh-Guldberg 1999). This often manifests as a "bleaching" of host tissue resulting from the expulsion or degradation of the symbionts and/or their photosynthetic pigments (Hoegh-Guldberg 1999). 
Coral bleaching can lead to mortality (Jones 2008), depressed growth rates (Goreau and MacFarlane 1990), and a heightened susceptibility to pathogens (Mydlarz et al. 2010). While much is known about its ecological consequences (see Pratchett et al. 2009 for review), comparatively little is understood regarding the cellular physiology of bleaching (Weis 2008). This is especially true for the phenomenon of differential bleaching, where corals vary in their responses to elevated temperatures (Weis 2010).

The differential bleaching susceptibility of reef corals is an emergent property of the genotypic composition of the resident Symbiodinium population (Rowan et al. 1997; Sampayo et al. 2008), previous thermal history (Guest et al. 2012) and physiological and life-history characteristics of the host (Baird et al. 2008 for review; Fitt et al. 2009; Palmer et al. 2010; Putnam et al. 2012). The latter in particular is becoming recognised as important in determining bleaching susceptibility; corals that associate with multiple Symbiodinium genotypes and acquire these symbionts from the environment are more sensitive to environmental stress than are species with maternal symbiont transmission and high symbiotic specificity (Putnam et al. 2012). However, this recognition of the host's role is a comparatively recent development as the coral bleaching field has been dominated by studies examining the role of the dinoflagellate symbiont (Jones et al. 1998; Warner et al. 1999; Baker 2001; Berkelmans and van Oppen 2006; Fisher et al. 2012). This is partly the result of a hypothesis that bleaching is "adaptive" for reef corals (Buddemeier and Fautin 1993; Baker 2001) and partly a consequence of our rapidly improving knowledge of symbiont phylogenetics (nine Symbiodinium "clades" and numerous "subclades" are now recognised; LaJeunesse 2002; Pochon et al. 2006). Examination of Symbiodinium photophysiology (Jones et al. 1998; Warner et al. 1999) contributed to the development of a model of coral bleaching as a consequence of symbiont photosynthetic dysfunction. Overproduction of reactive oxygen species (ROS), the onset of oxidative stress, and subsequent cellular damage were proposed as the proximate causes of this symbiotic collapse (Downs et al. 2002). Temperature- and light-induced ROS generation have been experimentally confirmed in Symbiodinium (Lesser 1996; Lesser 2006 for review; Suggett et al. 2008; Saragosti et al. 2010), but damage to host tissue in the absence of symbiont dysfunction (Gates et al. 1992; Nii and Muscatine 1997; Dunn et al. 2004, 2012; Paxton et al. 2013) and the release of photosynthetically competent and viable symbionts from bleaching corals (Ralph et al. 2001; Hill and Ralph 2007) have also been reported. Clearly, not all thermal bleaching in corals is symbiontdriven (Baird et al. 2008; Tolleter et al. 2013).

One component of host physiology that is relevant during temperature stress involves nitric oxide (NO). The synthesis of NO, an antimicrobial and cell-signalling molecule (Wink and Mitchell 1998; Fang 2004; Wang and Ruby 2011), has been reported in symbiotic cnidarians (Perez and Weis 2006) and dinoflagellates (Trapido-Rosenthal et al. 2001; Bouchard and Yamasaki 2008; Hawkins and Davy 2012). In the host, NO generation during temperature stress is thought to form part of an innate immune-like response mediating the ejection of Symbiodinium cells from the symbiosis (Perez and Weis 2006; Weis 2008; Detournay and Weis 2011; Detournay et al. 2012). The negative effects of NO on Symbiodinium physiology (Hawkins and Davy 2012) and the links between host NO synthesis and host apoptotic-like pathway activation (Hawkins et al. 2013) support this hypothesis. Apoptosis is a highly conserved mechanism of programmed cell death (Kerr et al. 1972) that is regulated by caspase enzymes (Lasi et al. 2010). It is an important mechanism of symbiont loss during coral bleaching (Dunn et al. 2004; Weis 2008; Pernice et al. 2011) and is also a pathogen-removal strategy in metazoans (Carmen and Sinai 2007). The modification of apoptotic pathways has already been proposed as a mechanism for differential host cell survival post-bleaching (Tchernov et al. 2011), and the anemone A. pallida generates NO to differing degrees during heat stress depending on the dominant in hospite symbiont genotype (Perez 2007). An interesting question, therefore, concerns the extent to which differential regulation of $\mathrm{NO}$ synthesis and potential downstream processes such as apoptosis, for example, could influence the stability of different coral-dinoflagellate associations during stress.

This investigation aimed to test the hypothesis that the differential generation of nitric oxide might be involved in the differing susceptibilities of reef corals under thermal bleaching. Thus, the species selected for this study were chosen on the basis of their sensitivities to elevated temperature. We hypothesised that heating would result in the elevated synthesis of NO in host and symbiont and that host NO synthesis would correlate with the induction of apoptotic-like cell death pathways known to be involved in bleaching (Dunn et al. 2004; Pernice et al. 2011; Tchernov et al. 2011). We also hypothesised that these events (in the host) are consequences of symbiont photophysiological dysfunction (Perez and Weis 2006). Here, we provide physiological data that may have implications for our understanding of differential thermal bleaching in corals.

\section{Materials and methods}

Unless otherwise stated, all reagents were obtained from Sigma-Aldrich (Auckland, New Zealand) and were of the highest analytical grade available. 
Collection and treatment of coral fragments

Fragments (ca. $5 \mathrm{~cm}$ length, $3 \mathrm{~cm}$ width) of A. millepora (cream morph), P. damicornis (pink morph), and M. digitata (green morph) were collected from Heron Island reef flat (Great Barrier Reef (GBR), Australia; $23^{\circ} 26^{\prime} 43^{\prime \prime} \mathrm{S}$, $\left.151^{\circ} 54^{\prime} 53^{\prime \prime} \mathrm{E}\right)$ at low tide under the GBR Marine Park permit G12/34800.1. Fragments were transferred to flowthrough aquaria and fixed to synthetic clay mounts using a small quantity (ca. $1 \mathrm{~cm}^{2}$ ) of epoxy putty (Aqua Knead-It, Selleys, Padstow, NSW, Australia). Mounted fragments were then placed in experimental 60-L tanks under shade cloth (reducing incident midday irradiance from ca. 2,000 to $400-600 \mu \mathrm{mol}$ photons $\mathrm{m}^{-2} \mathrm{~s}^{-1}$ ). Four fragments were sampled from each of five replicate colonies, which were separated by at least $10 \mathrm{~m}$ on the reef flat in order to increase the likelihood of sampling genetically distinct individuals. A continuous flow system (ca. $1.5 \mathrm{~L} \mathrm{~min}^{-1}$ ) ensured a constant turnover of seawater (from Heron Island reef flat), and fragments were acclimated for $6 \mathrm{~d}$ at $28.5^{\circ} \mathrm{C}$ $\left( \pm 0.9{ }^{\circ} \mathrm{C}, \mathrm{SD}\right)$, a temperature characteristic of summer daytime conditions on Heron Island reef flat (AIMS; http://data.aims.gov.au/aimsrtds/station.xhtml?station=130). Additional water flow was provided by a submersible pump (HX-6830, HAILEA, RaoPing, GuangDong, China). After the acclimation period, the temperature of two of the tanks was increased by approximately $1{ }^{\circ} \mathrm{C}$ per day (Electronic Supplemental Material ESM Fig. S1) and stabilised at either $31.5^{\circ} \mathrm{C}\left( \pm 0.6{ }^{\circ} \mathrm{C}\right)$ or $33{ }^{\circ} \mathrm{C}\left( \pm 0.8^{\circ} \mathrm{C}\right)$. Water temperatures were monitored every 5 min using HOBO data loggers (Onset Computer Corporation, Bourne, MA, USA).

Fluorometric assessment of in hospite symbiont photosystem II (PSII)

Efficiency of symbiont PSII was measured using pulse amplitude modulation fluorometry (Diving-PAM, Walz, Effeltrich, Germany). Maximum (dark-adapted) quantum yields of PSII $\left(F_{\mathrm{v}} / F_{\mathrm{m}}\right)$ were recorded daily, 30 min after sunset. Presented values are means of triplicate measurements of coral fragments designated for the final sampling point.

\section{Coral fragment processing}

Fragments were removed from experimental tanks shortly after noon on days $0,5,7$, and 9 (ESM Fig. S1), wrapped in aluminium foil, flash-frozen in liquid nitrogen, and stored at $-80{ }^{\circ} \mathrm{C}$. All subsequent procedures were carried out in a $4{ }^{\circ} \mathrm{C}$ environment or on ice unless otherwise stated.

Tissue was removed from coral fragments by airbrushing (using the low pressure outlet of a SCUBA-diving regulator; Apeks Marine Ltd., Blackburn, Lancs., UK) into a zip- lock bag containing a known volume of $50 \mathrm{mM}$ potassium phosphate, $\mathrm{pH}$ 7.8, $1 \mathrm{mM}$ EDTA homogenisation buffer (HB; prepared using 18.3 M $\Omega$ water). Tissue suspensions were homogenised with a sawtooth homogeniser (Labserv D-130, Thermo Fisher Scientific, Albany, New Zealand) for $10 \mathrm{~s}$ at $20,000 \mathrm{rpm}$. Two $500-\mu \mathrm{L}$ aliquots were removed for Symbiodinium cell counts (and to confirm the structural integrity of cells post-homogenisation) and photosynthetic pigment analysis. Samples for cell counting were fixed with $10 \mu \mathrm{L}$ Lugols solution and stored at $-20{ }^{\circ} \mathrm{C}$. Pigment samples were centrifuged $(16,000 \times g$ for $5 \mathrm{~min})$, the supernatant discarded, and the pellet frozen and stored at $-20{ }^{\circ} \mathrm{C}$ in the dark. The remaining tissue homogenate was centrifuged $(1,500 \times g$ for $5 \mathrm{~min})$ to separate remaining Symbiodinium cells from host material. The supernatant was removed and stored in $1-\mathrm{mL}$ aliquots at $-80{ }^{\circ} \mathrm{C}$ alongside the algal pellet.

Quantification of bleaching in coral fragments

Symbiodinium cell densities were quantified using haemocytometer counts (Improved Neubauer, Boeco, Germany), with at least six counts per sample (until coefficients of variability were $<15 \%$ ). Cell density was normalised to coral fragment surface area, measured with the wax-dipping method (Stimson and Kinzie 1991). Symbiont chlorophyll $a(\mathrm{Chl} a)$ content was quantified by $N, N$ dimethylformamide (DMF) extraction carried out in darkness over $48 \mathrm{~h}$ at $4{ }^{\circ} \mathrm{C}$. Extracts were centrifuged $(16,000 \times g$ for $5 \mathrm{~min})$ and triplicate $200-\mu \mathrm{L}$ aliquots were measured in 96-well plates (UVStar, Greiner Bio-One $\mathrm{GmbH}$, Germany) at 646.8, 663.8, and $750 \mathrm{~nm}$ using a microplate reader (Enspire ${ }^{\circledR}$ 2300, Perkin-Elmer, Waltham, MA, USA). Chl $a$ concentrations were determined after optical path length correction $(0.555 \mathrm{~cm})$ using the equations of Porra et al. (1989).

\section{Identification of dominant in hospite Symbiodinium} genotypes

Symbiodinium aliquots were washed three times in HB $(2,000 \times g$ for $5 \mathrm{~min})$ and cells were processed following the methods of Logan et al. (2010). PCR amplification of the internal transcribed spacer-2 (ITS2) region of the nuclear ribosomal DNA was carried out using the forward primer ITS-D (5'-GTGAATTGCAGAACTCCGTG-3') and reverse primer ITS2-Rev2 (5'-CCTCCGCCTACTTATATGCTT- $3^{\prime}$ ). All PCR amplicons were checked for correct size via gel electrophoresis $(1.5 \%$ [w/v] agarose gel), purified (ExoSAP-IT; GE Healthcare, Life Sciences), and sequenced in both directions by Macrogen Korea (Seoul, South Korea). Sequences were identified using the NCBI and GeoSymbio databases (Franklin et al. 2012). 
Preparation of Symbiodinium cell lysates

Frozen Symbiodinium pellets were washed four times with $\mathrm{HB}$ by repeated centrifugation $(800 \times g$ for $5 \mathrm{~min})$ to remove host material. The cell suspension was transferred to a 1.5$\mathrm{mL}$ tube containing $50 \mathrm{mg}$ acid-washed glass beads (710-1,180 $\mu \mathrm{m}$; Sigma-Aldrich, Auckland, New Zealand). Cells were lysed in a bead-mill (Tissuelyser LT, Qiagen Inc., Hilden, Germany) for $10 \mathrm{~min}$ at a frequency of $50 \mathrm{~Hz}$. Visual counts (haemocytometer) confirmed cellular disruption, and the cell lysate was immediately analysed.

\section{Quantification of the proxies for NO production}

Flash-freezing corals in the field limits the live, real-time quantification of NO (with confocal microscopy and fluorescent dyes, for example; Perez and Weis 2006). However, $\mathrm{NO}$ in biological systems is quickly oxidised to either nitrite $\left(\mathrm{NO}_{2}{ }^{-}\right)$or nitrate $\left(\mathrm{NO}_{3}{ }^{-}\right)$(Bryan and Grisham 2007), and these biomarkers have been used to successfully quantify cnidarian NO synthesis (Detournay and Weis 2011; Detournay et al. 2012; Hawkins et al. 2013). The relative contributions of $\mathrm{NO}_{2}{ }^{-}$and $\mathrm{NO}_{3}{ }^{-}$to total oxidised $\mathrm{NO}$ $\left(\mathrm{NO}_{\mathrm{x}}^{-}\right)$depend on the immediate cellular environment at the sites of NO synthesis (Bryan and Grisham 2007), so overall assessments of NO synthesis benefit from measurements of total oxidised $\mathrm{NO}\left(\mathrm{NO}_{\mathrm{x}}^{-}\right.$; the sum of $\mathrm{NO}_{2}{ }^{-}$and $\left.\mathrm{NO}_{3}{ }^{-}\right)$.

\section{Nitrite $\left(\mathrm{NO}_{2}{ }^{-}\right)$assay}

Sample $\mathrm{NO}_{2}{ }^{-}$content was calculated using the fluorescent indicator 2,3-diaminonaphthalene (DAN, Invitrogen, Auckland, New Zealand; Nussler et al. 2006) according to the methods of Hawkins et al. (2013). Host homogenates and symbiont cell lysates were centrifuged $(16,000 \times g$ for $20 \mathrm{~min}$ ) prior to processing, and DAN fluorescence (excitation: $365 \mathrm{~nm}$, emission: $410 \mathrm{~nm}$ ) was measured using a microplate reader (Enspire ${ }^{\circledR}$ 2300, Perkin-Elmer, Waltham, MA, USA). Negative controls (using HB instead of sample) were prepared in order to control for unreacted DAN fluorescence (a false positive), and $\mathrm{NO}_{2}{ }^{-}$-dependent fluorescence was calculated relative to that of a sample blank in order to control for the significant autofluorescence of reef coral homogenates (Palmer et al. 2010). A calibration curve of $10-10,000 \mathrm{nM} \mathrm{NaNO} 2$ in $\mathrm{HB}$ was used to determine final sample $\mathrm{NO}_{2}{ }^{-}$concentrations.

\section{Total oxidised $\mathrm{NO}\left(\mathrm{NO}_{x}{ }^{-}\right)$assay}

Quantification of total $\mathrm{NO}_{\mathrm{x}}{ }^{-}$with DAN requires the reduction of nitrate to nitrite, and this was achieved by adding $66 \mu \mathrm{L} 0.1 \mathrm{M}$ vanadium (III) chloride $\left(\mathrm{VCl}_{3}\right)$ solution in $1 \mathrm{~N} \mathrm{HCl}$ (Miranda et al. 2001) to the sample (centrifuged as above) prior to the addition of the DAN reagent. Addition of DAN solution to Symbiodinium cell lysates in the presence of $\mathrm{VCl}_{3}$ promoted the development of a persistent and interfering blue colour that quenched DAN fluorescence and could not be removed; these samples were therefore not included in the analysis. Host homogenates were incubated as described previously (Hawkins et al. 2013) and DAN fluorescence was quantified using a microplate reader (see above) and a calibration curve of $10-10,000 \mathrm{nM} \mathrm{NaNO}$ in $\mathrm{HB}$. Again, negative controls (using $\mathrm{HB}$ instead of sample) were prepared in order to control for unreacted DAN fluorescence (a false positive), and final $\mathrm{NO}_{\mathrm{x}}{ }^{-}$-dependent fluorescence was calculated relative to autofluorescence-only sample blanks.

As positive controls, homogenates of untreated (Day 0) corals from each species were incubated for $4 \mathrm{~h}$ with $1 \mathrm{mM}$ of the NO donor sodium nitroprusside (SNP).

\section{Assessment of caspase-like enzyme activity}

The activity of enzymes resembling mammalian caspase-3 (an "executioner" caspase; Lasi et al. 2010) and caspase-9 (an "initiator" caspase in the mitochondrial pathway; Lasi et al. 2010) was quantified using a colorimetric assay kit (Sigma-Aldrich, Auckland, New Zealand) with the substrates Ac-Asp-Glu-Val-Asp-pNA (Ac-DEVD-pNA) and Ac-Leu-Glu-His-Asp-pNA (Ac-LEHD-pNA), respectively (Hawkins et al. 2013). Caspase-like enzymes cleave these tetrapeptide substrates at the terminal aspartic acid residue with a specificity determined by the identity of the preceding three amino acid residues. Briefly, coral host homogenates were thawed on ice and centrifuged $(16,000 \times g$ for $20 \mathrm{~min})$. Aliquots of the supernatant were removed for protein quantification [Bradford assay with bovine serum albumin (BSA) as a standard (Bradford 1976)], and duplicate aliquots of the remainder were removed for caspase-like enzyme analysis. Briefly, ten microlitres XXXX-pNA substrate (2 mM) was mixed with $40 \mu \mathrm{L}$ "assay buffer" [20 mM 4-(2-hydroxyethyl)-1piperazineethanesulfonic acid (HEPES), pH 7.4, $2 \mathrm{mM}$ EDTA, $0.1 \%$ 3-[(3-cholamidopropyl)-dimethylammonio]1-propanesulfonate (CHAPS), $5 \mathrm{mM}$ dithiothreitol (DTT)], and $50 \mu \mathrm{L}$ coral homogenate. After gentle shaking for $10 \mathrm{~s}$, samples were incubated according to the manufacturer's instructions. Sample blanks (minus caspase substrates) were prepared in order to control for sample absorbance, and to control for false positives caused by substrate autolysis, reagent blanks (using $\mathrm{HB}$ instead of sample) were measured alongside. To further determine the rate of non-specific substrate hydrolysis by coral homogenates, three untreated replicate samples from each coral species were pre-incubated for $30 \mathrm{~min}$ with $20 \mu \mathrm{M}$ DEVD- or 
LEHD-aldehyde (-CHO), inhibitors of caspase-3 and caspase-9, respectively.

\section{Statistical analyses}

Data analysis was carried out with PASW Statistics 18.0 (IBM, Armonk, NY, USA). Where appropriate, data were analysed using repeated measures analysis of variance (RMANOVA) with Greenhouse-Geisser correction used whenever Mauchly's test returned a significant result. RMANOVA post hoc tests represent pairwise comparisons between treatments at certain time points with Bonferroni correction. Multivariate ANOVA (MANOVA) was used to examine baseline caspase-like enzyme activity, and additional analyses were carried out using one-way ANOVA. Data were log-transformed (or arcsine square root-transformed, in the case of $\left.F_{\mathrm{v}} / F_{\mathrm{m}}\right)$ prior to parametric analysis.

\section{Results}

\section{Symbiodinium genotypes}

Dominant in hospite ITS2 genotypes were as follows: Acropora millepora-C3; Montipora digitata-C15; and Pocillopora damicornis-C42 (type 2). All colonies of each species harboured the same ITS2 type and the nature of returned ITS2 sequences suggested the presence of a single symbiont genotype within individual colonies.

PSII fluorescence and bleaching of reef corals at elevated temperature

Exposure to elevated temperature for 9 days led to significant declines in the dark-adapted PSII quantum yields $\left(F_{\mathrm{v}} / F_{\mathrm{m}}\right)$ of all three species (Table 1$)$, and these responses differed significantly between species (RMANOVA, time $\times$ species $\times$ temperature, $\left.F_{4.4,48.6}=56.86, P<0.001\right)$. $F_{\mathrm{v}} / F_{\mathrm{m}}$ in A. millepora and $P$. damicornis (initially $0.68 \pm 0.01$ and $0.64 \pm 0.01$ [both $\pm \mathrm{SEM}$ ], respectively) declined to $0.34 \pm 0.01$ and $0.49 \pm 0.02$, respectively (Fig. $1 \mathrm{a}-\mathrm{c}$ ). $F_{\mathrm{v}} / F_{\mathrm{m}}$ in $M$. digitata remained at the control level until late in the experiment when a slight but statistically significant decrease became apparent (Fig. 1b). Data are not available for $P$. damicornis after 6 days at $33{ }^{\circ} \mathrm{C}$ when fragments suffered $100 \%$ mortality (visible as tissue sloughing); physiological analyses were therefore carried out on fragments incubated at $31.5{ }^{\circ} \mathrm{C}$.

Baseline Chl a content differed between ITS2 types (one-way ANOVA, $F_{2,28}=23.67, P<0.001$ ); the $\mathrm{C} 42$ (type 2), symbionts of $P$. damicornis had the highest amount per cell (6.9 pg \pm 0.1 , Tukey HSD post hoc, $P<0.01$ for both comparisons), and the C3 symbionts of
Table 1 Statistical analysis (RMANOVA, time $\times$ temperature interaction) of symbiont physiological parameters in reef corals exposed to control $\left(28.5^{\circ} \mathrm{C}\right)$ and elevated temperatures $\left(31.5^{\circ} \mathrm{C}\right.$ for Pocillopora damicornis; $33{ }^{\circ} \mathrm{C}$ for Acropora millepora and Montipora digitata)

\begin{tabular}{|c|c|c|c|}
\hline $\begin{array}{l}\text { Species } \\
\text { (ITS2 type) }\end{array}$ & Parameter & $F$ value & $P$ value \\
\hline \multirow{3}{*}{$\begin{array}{l}\text { Acropora millepora } \\
\text { (C3) }\end{array}$} & $F_{\mathrm{v}} / F_{\mathrm{m}}$ & $F_{1.4,8.5}=186.22$ & $<0.001 *$ \\
\hline & $\begin{array}{c}\text { Chlorophyll } \\
a \text { content }\end{array}$ & $F_{3,21}=1.834$ & 0.172 \\
\hline & $\begin{array}{l}\text { Nitrite }\left(\mathrm{NO}_{2}^{-}\right) \\
\text {content }\end{array}$ & $F_{3,15}=6.771$ & $0.043 *$ \\
\hline \multirow{3}{*}{$\begin{array}{l}\text { Montipora digitata } \\
\text { (C15) }\end{array}$} & $F_{\mathrm{v}} / F_{\mathrm{m}}$ & $F_{3.1,26.7}=9.99$ & $<0.001 *$ \\
\hline & $\begin{array}{c}\text { Chlorophyll } \\
a \text { content }\end{array}$ & $\mathrm{F}_{3,24}=4.18$ & $0.016^{*}$ \\
\hline & $\begin{array}{l}\text { Nitrite }\left(\mathrm{NO}_{2}^{-}\right) \\
\text {content }\end{array}$ & $F_{3,15}=0.407$ & 0.75 \\
\hline $\begin{array}{l}\text { Pocillopora } \\
\text { damicornis }\end{array}$ & $F_{\mathrm{v}} / F_{\mathrm{m}}$ & $F_{1.7,13.7}=30.23$ & $<0.001 *$ \\
\hline \multirow[t]{2}{*}{ (C42) } & $\begin{array}{c}\text { Chlorophyll } \\
a \text { content }\end{array}$ & $F_{3,21}=0.84$ & 0.487 \\
\hline & $\begin{array}{l}\text { Nitrite }\left(\mathrm{NO}_{2}^{-}\right) \\
\text {content }\end{array}$ & $F_{3,18}=1.137$ & 0.361 \\
\hline
\end{tabular}

* Statistical significance $(P<0.05)$

A. millepora had the lowest amount per cell (3.3 pg \pm 0.2 , Tukey HSD post hoc, $P<0.05$ for both comparisons). C3 was the only type to display declining $\mathrm{Chl} a$ content at elevated temperature and, while there was no significant time $\times$ treatment interaction (Table 1), type C3 cells at $33{ }^{\circ} \mathrm{C}$ contained $58 \%$ less $\mathrm{Chl} a$ after 9 days than did the equivalent controls (Fig. 1d).

Pre-treatment symbiont densities differed significantly between species (one-way ANOVA with Welch correction, $\left.F_{2,10.8}=39.29, P<0.001\right)$, with $P$. damicornis having $80 \%$ fewer Symbiodinium cells per $\mathrm{cm}^{2}$ than the two other species (Tukey HSD post hoc, $P<0.01$ for both comparisons). When incubated at elevated temperature $\left(31.5^{\circ} \mathrm{C}\right.$ for $P$. damicornis or $33{ }^{\circ} \mathrm{C}$ for A. millepora and M. digitata) for 9 days, symbiont densities declined significantly in A. millepora and P. damicornis (to ca. 10 and $50 \%$ of initial densities, respectively) and no significant changes were observed in M. digitata (Table 2; Fig. 1g-i).

Nitrite and total oxidised NO in reef corals at elevated temperature

Nitrite $\left(\mathrm{NO}_{2}{ }^{-}\right)$levels (nmol per unit soluble protein) in the type C3 Symbiodinium cells of A. millepora increased significantly at elevated temperature (Table 1; Fig. 2a), but this was only apparent on day 9 of the treatment. An increasing trend was apparent in the symbionts of $P$. damicornis but no significant time $\times$ temperature interaction was observed (Table 1; Fig. 2c). No changes in 


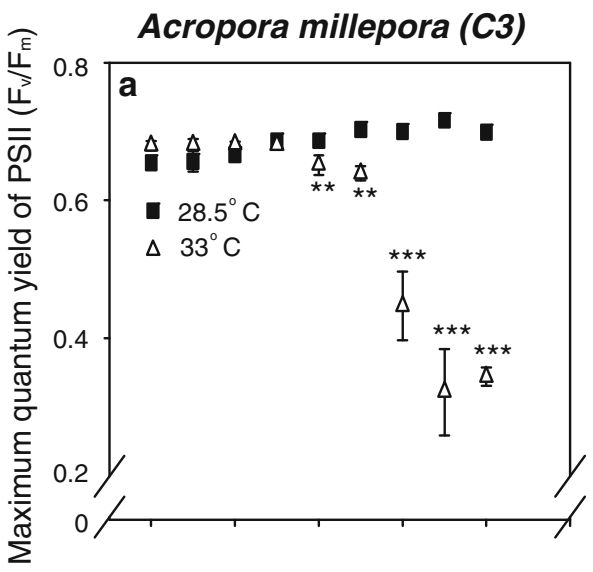

Montipora digitata (C15)
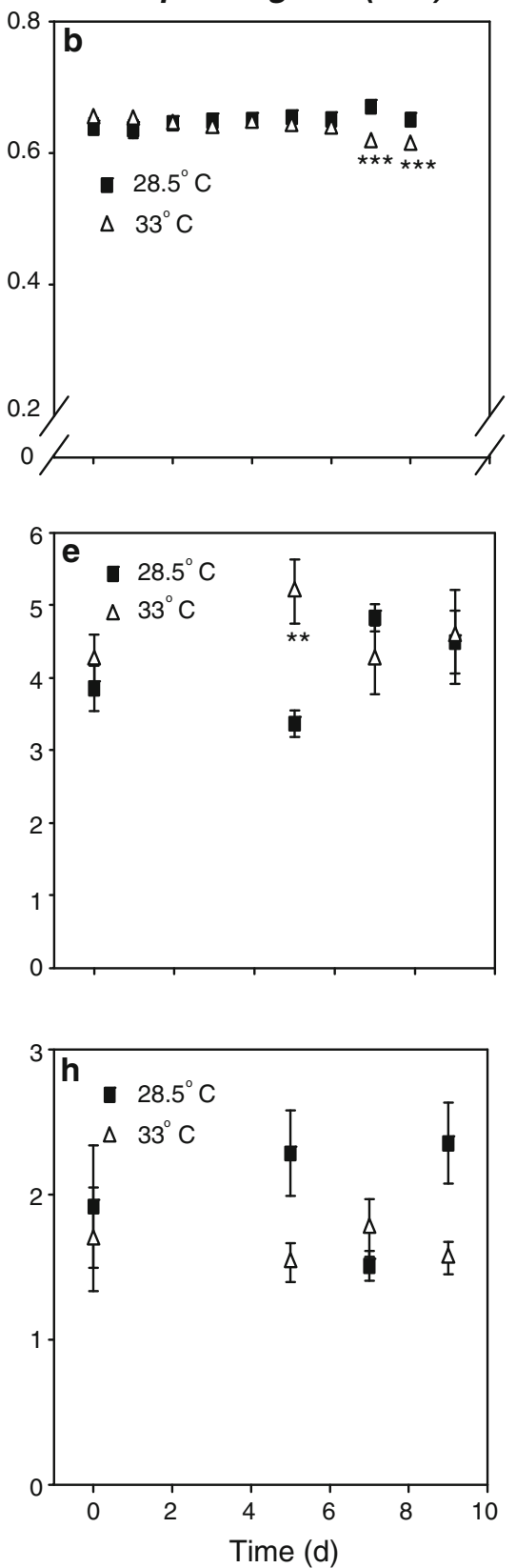

Pocillopora damicornis (C42)
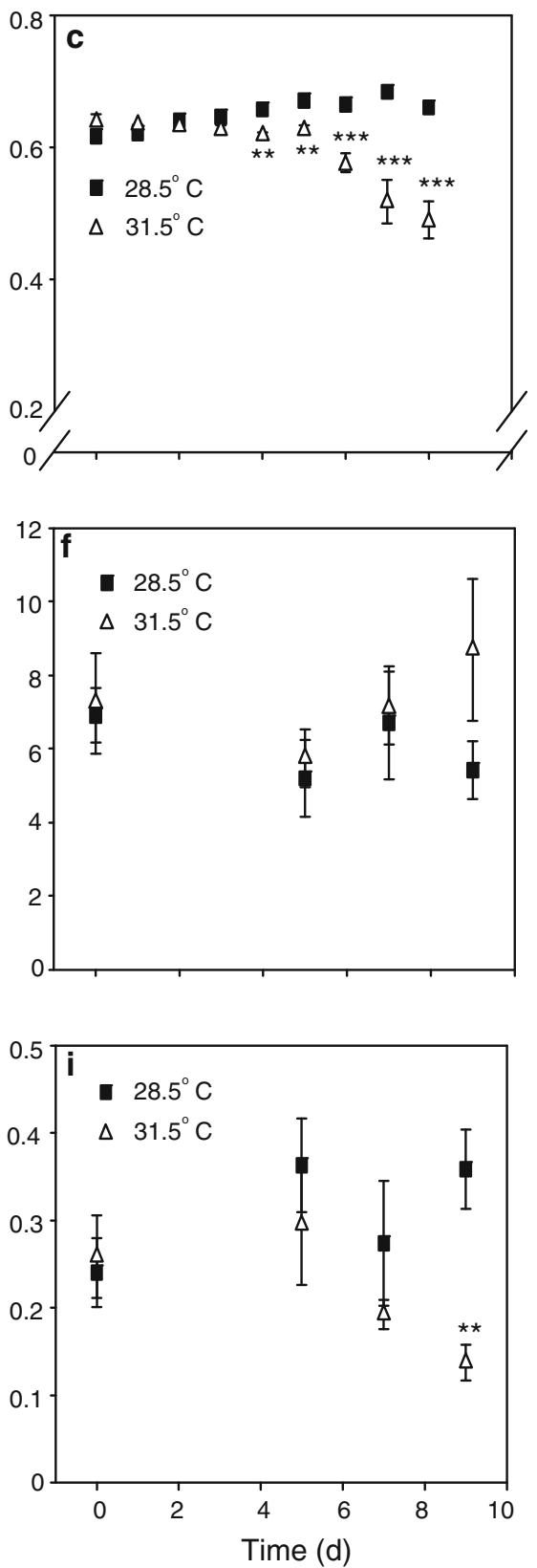

Fig. 1 Quantum yields of photosystem II, symbiont chlorophyll $a$ content and density in Acropora millepora, Montipora digitata and Pocillopora damicornis. a-c Maximum quantum yield of photosystem II $\left(F_{\mathrm{v}} / F_{\mathrm{m}}\right) ; \mathbf{d}-\mathbf{f}$ Chlorophyll $a$ content (pg per cell); $\mathbf{g}-\mathbf{i}$ Symbiont cell density per $\mathrm{cm}^{2}$ coral fragment surface. Values are mean \pm SEM

cellular $\mathrm{NO}_{2}{ }^{-}$were observed in the $\mathrm{C} 15$ symbionts of Montipora digitata (Fig. 2b).

Host tissue $\mathrm{NO}_{2}^{-}$(pmol per unit soluble protein) differed significantly between species at the start of the experiment (one-way ANOVA with Welch correction, $\left.F_{2,12.5}=28.55, \quad P<0.001\right)$, with $A$. millepora having significantly (approximately twofold) higher host tissue $\mathrm{NO}_{2}{ }^{-}$than the other two species (Tukey HSD post hoc, and asterisks denote significant differences relative to controls at each time point (RMANOVA, pairwise post hoc with Bonferroni correction, $n=5$ independent colonies per time point except $A$. millepora after $7 \mathrm{~d}$ at $33{ }^{\circ} \mathrm{C}$ where $n=4, \quad * P<0.05, \quad * * P<0.01$, $* * * P<0.001)$. Note the different $y$-axis scales in $\mathbf{d}-\mathbf{f}$ and $\mathbf{g}-\mathbf{i}$

$P<0.01$ for both comparisons). However, tissue $\mathrm{NO}_{2}{ }^{-}$ content did not respond to temperature in any of the coral species (Table 2, ESM Fig. S2). Baseline total oxidised NO $\left(\mathrm{NO}_{\mathrm{x}}{ }^{-}\right)$concentrations in the host also differed between species (one-way ANOVA with Welch correction, $\left.F_{2,12.7}=4.01, P=0.045\right)$, but in this case A. millepora and $M$. digitata had similar $\mathrm{NO}_{\mathrm{x}}{ }^{-}$levels while those of $P$. damicornis were lower $(\leq 35 \%$; Tukey HSD post hoc, 
Table 2 Statistical analysis (RMANOVA, time $\times$ temperature interaction) of host physiological parameters in reef corals exposed to control $\left(28.5{ }^{\circ} \mathrm{C}\right)$ and elevated temperatures $\left(31.5^{\circ} \mathrm{C}\right.$ for Pocillopora damicornis; $33{ }^{\circ} \mathrm{C}$ for Acropora millepora and Montipora digitata)

\begin{tabular}{|c|c|c|c|}
\hline Species & Parameter & $F$ value & $P$ value \\
\hline \multirow{5}{*}{$\begin{array}{l}\text { Acropora } \\
\text { millepora }\end{array}$} & Tissue nitrite $\left(\mathrm{NO}_{2}^{-}\right)$ & $F_{3,18}=0.89$ & 0.465 \\
\hline & $\begin{array}{l}\text { Tissue total oxidised } \\
\mathrm{NO}\left(\mathrm{NO}_{\mathrm{x}}^{-}\right)\end{array}$ & $F_{3,18}=6.614$ & $0.031 *$ \\
\hline & $\begin{array}{l}\text { LEHDase (caspase- } \\
\text { 9-like) activity }\end{array}$ & $F_{3,21}=3.82$ & $0.025^{*}$ \\
\hline & $\begin{array}{l}\text { DEVDase (caspase- } \\
\text { 3-like) activity }\end{array}$ & $F_{3,21}=7.313$ & $0.002 *$ \\
\hline & Symbiont density & $F_{3,18}=6.572$ & $0.003^{*}$ \\
\hline \multirow{5}{*}{$\begin{array}{c}\text { Montipora } \\
\text { digitata }\end{array}$} & Tissue nitrite $\left(\mathrm{NO}_{2}^{-}\right)$ & $F_{3,18}=0.232$ & 0.873 \\
\hline & $\begin{array}{l}\text { Tissue total oxidised } \\
\mathrm{NO}\left(\mathrm{NO}_{\mathrm{x}}^{-}\right)\end{array}$ & $F_{1.6,9.5}=1.23$ & 0.321 \\
\hline & $\begin{array}{l}\text { LEHDase (caspase- } \\
\text { 9-like) activity }\end{array}$ & $F_{3,24}=0.085$ & 0.968 \\
\hline & $\begin{array}{l}\text { DEVDase (caspase- } \\
\text { 3-like) activity }\end{array}$ & $F_{3,24}=0.464$ & 0.633 \\
\hline & Symbiont density & $F_{3,18}=1.426$ & 0.268 \\
\hline \multirow{5}{*}{$\begin{array}{l}\text { Pocillopora } \\
\text { damicornis }\end{array}$} & Tissue nitrite $\left(\mathrm{NO}_{2}{ }^{-}\right)$ & $F_{3,18}=1.672$ & 0.209 \\
\hline & $\begin{array}{l}\text { Tissue total oxidised } \\
\mathrm{NO}\left(\mathrm{NO}_{\mathrm{x}}^{-}\right)\end{array}$ & $F_{3,12}=3.920$ & $0.037 *$ \\
\hline & $\begin{array}{l}\text { LEHDase (caspase- } \\
\text { 9-like) activity }\end{array}$ & $F_{3,24}=5.416$ & $0.005^{*}$ \\
\hline & $\begin{array}{l}\text { DEVDase (caspase- } \\
\text { 3-like) activity }\end{array}$ & $F_{1.5,11.7}=4.71$ & $0.04 *$ \\
\hline & Symbiont density & $F_{3,21}=4.779$ & $0.011 *$ \\
\hline
\end{tabular}

* Statistical significance $(P<0.05)$

$P<0.05)$. Tissue $\mathrm{NO}_{\mathrm{x}}{ }^{-}$in $A$. millepora and $P$. damicornis responded significantly to temperature over the experimental period (Table 2), with heightened $\mathrm{NO}_{\mathrm{x}}^{-}$levels observed on day 5 for both species (Fig. 2d, f). No significant changes in $\mathrm{NO}_{\mathrm{x}}{ }^{-}$content were seen in $M$. digitata (Table 2; Fig. 2e).

Responses of host caspase-like enzymes to elevated temperature

Baseline host caspase-like enzyme activity was highly variable between the three coral species (Fig. $2 \mathrm{~g}-\mathrm{i}$ ), with DEVDase (caspase-3-like) activity lower in M. digitata than in the other two species (one-way ANOVA, $F_{2,29}=42.58$, $P<0.001$, Fig. 2h). Further examination revealed no significant difference in substrate cleavage between $M$. digitata homogenates treated with and without caspase-like enzyme inhibitors (MANOVA, Pillai's Trace, $F_{3,12}=0.89$, $P=0.495$; Tukey HSD post hoc DEVDase: $P=0.867$,
LEHDase: $P=0.253)$. Effects of heating on host caspaselike enzyme activity differed depending on the species and the duration of treatment (Table 2; Fig. $2 \mathrm{~g}-\mathrm{i}$ ). No changes in DEVDase or LEHDase (caspase-9-like) activity were seen in M. digitata (Table 2; Fig. 2h). LEHDase and DEVDase activity in A. millepora and $P$. damicornis responded to increasing temperature (Table 2; Fig. $2 \mathrm{~g}-\mathrm{i}$ ), and after 5 days at $33{ }^{\circ} \mathrm{C}$ in A. millepora and 7 days at $31.5^{\circ} \mathrm{C}$ in $P$. damicornis, their activities were at least twofold higher than in control samples. This was followed by a slight decline in both species, although caspase-like enzyme activity remained significantly elevated in A. millepora throughout the treatment period.

\section{Discussion}

This study provides evidence that host-level responses such as nitric oxide synthesis and apoptotic-like cell death may be involved in the differential thermal bleaching of reef corals. We report marked differences in physiological responses to heating, even between two "temperaturesensitive" coral species. Furthermore, heightened host NO synthesis (measured as oxidised NO accumulation) and apoptotic pathway activation appeared to be initiated simultaneously in A. millepora. Perhaps most importantly, however, we observed substantial interspecific variability in the baseline activity of apoptotic-like pathways in the host. Together with recent investigations, these findings could contribute to a developing physiological framework describing the differing sensitivities of corals to warming oceans.

Photophysiological dysfunction, symbiont NO synthesis, and coral bleaching

Exposure to heating of $1{ }^{\circ} \mathrm{C}$ per day to $3-5{ }^{\circ} \mathrm{C}$ above ambient revealed significant differences in symbiont physiology and the overall bleaching susceptibility of the reef corals A. millepora, $M$. digitata, and $P$. damicornis. As observed previously, the $M$. digitata-C15 association was comparatively robust in its response to heating, while the A. millepora-C3 and P. damicornis-C42 (type 2) symbioses proved much more unstable (Fisher et al. 2012; Guest et al. 2012).

Consistent with the absence of chlorophyll $a$ degradation and the modest decline in $F_{\mathrm{v}} / F_{\mathrm{m}}$ in the C15-type symbiont cells of $M$. digitata, there was no evidence of upregulated symbiont NO synthesis-a thermal stress response (Bouchard and Yamasaki 2008) —in this species. In contrast, the symbionts of A. millepora and P. damicornis both displayed evidence of heightened NO production (accumulation of cellular nitrite) after 9 days of 
Acropora millepora (C3)
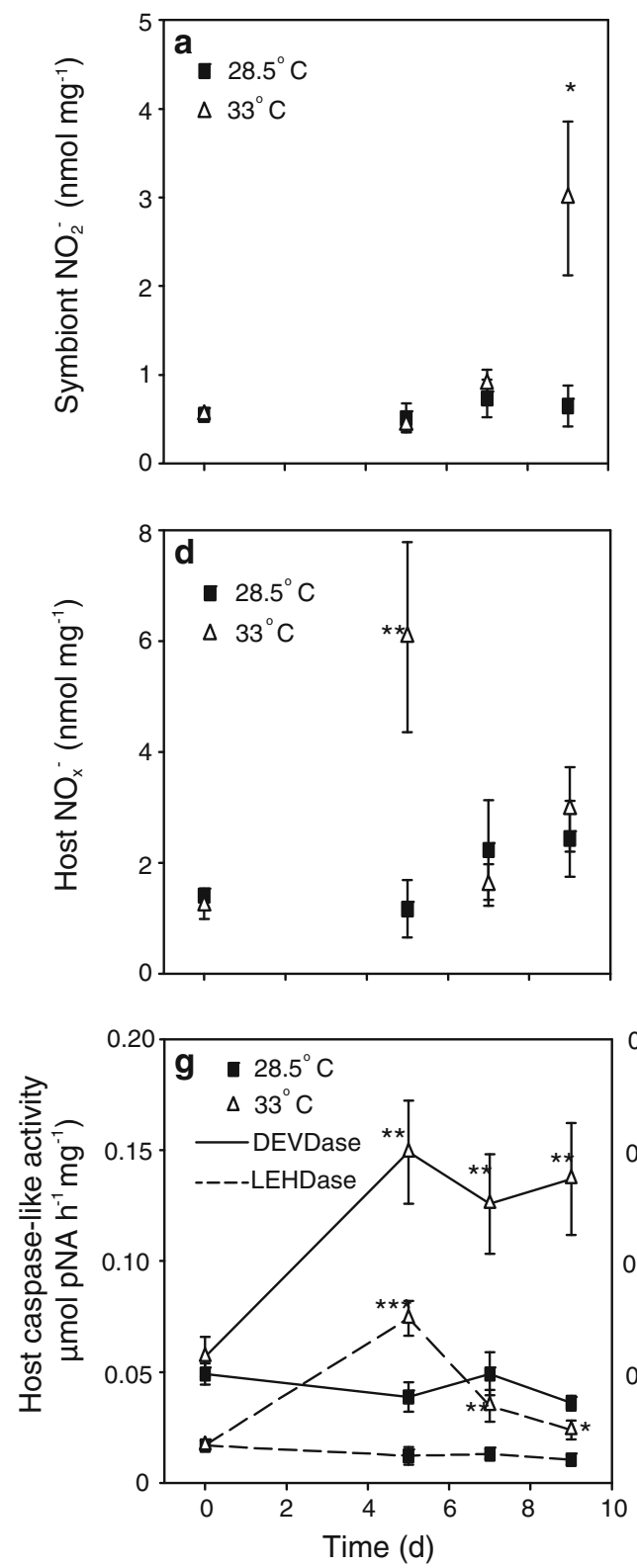

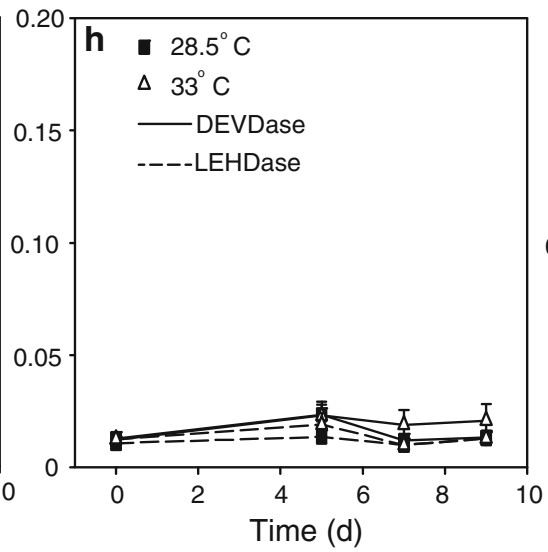

Montipora digitata (C15)
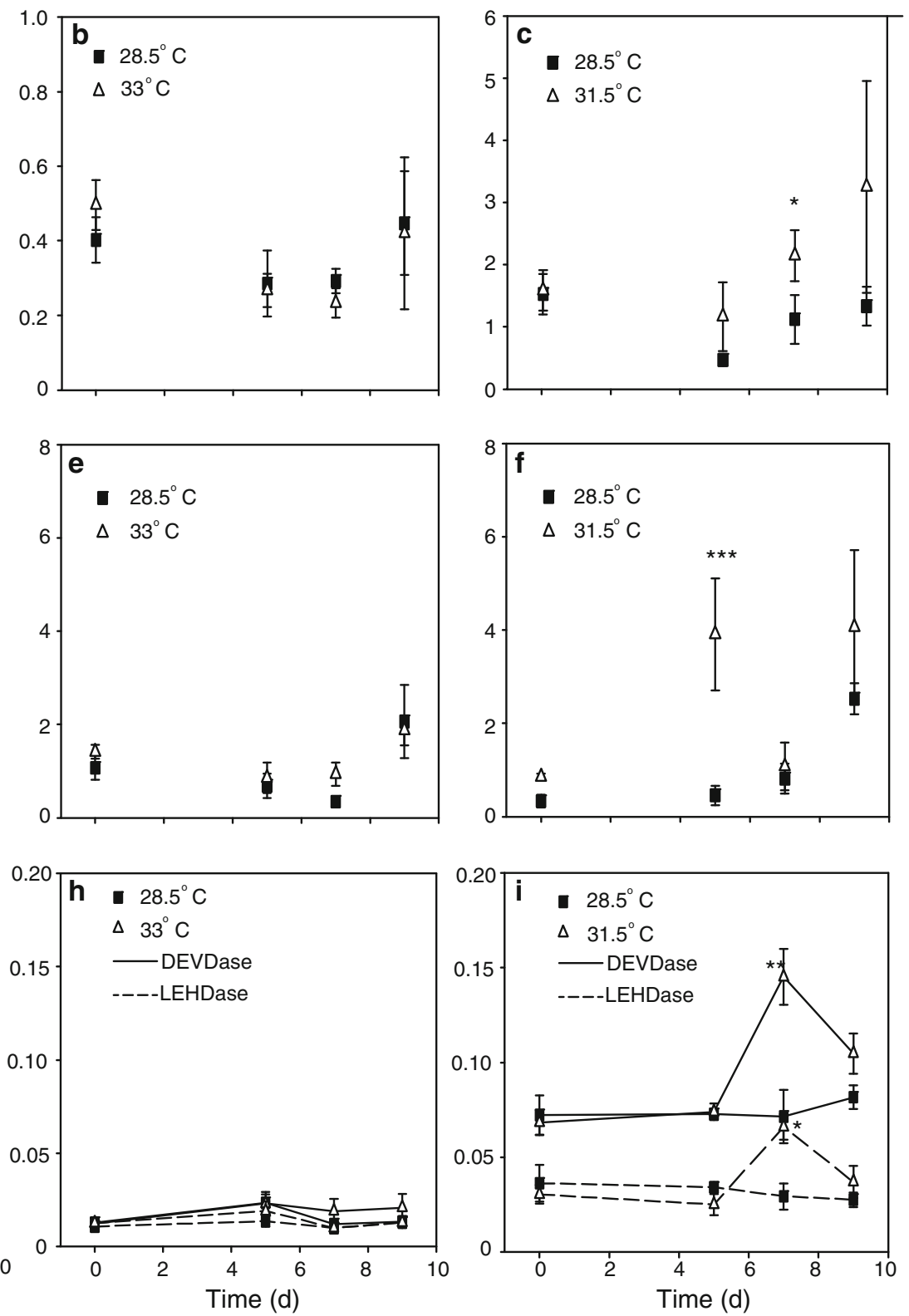

Pocillopora damicornis (C42)

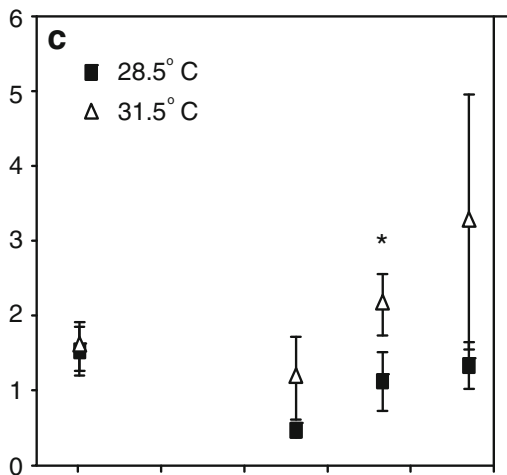

Fig. 2 Oxidised NO accumulation and apoptotic events in the reef corals Acropora millepora, Montipora digitata and Pocillopora damicornis. a-c Symbiont nitrite $\left(\mathrm{NO}_{2}{ }^{-}\right)$content (nmol per $\mathrm{mg}$ protein). d-f Host total oxidised $\mathrm{NO}\left(\mathrm{NO}_{\mathrm{x}}^{-}\right)$content (nmol per mg protein). g-i Host caspase-like enzyme activity (rate of substrate cleavage per mg protein). Values are mean \pm SEM and asterisks

exposure. The only previous study of $\mathrm{NO}$ in clade $\mathrm{C}$ Symbiodinium (Hawkins and Davy 2012) reported a temperature-induced downregulation of NO synthesis. This could be due to the use of cultured Symbiodinium cells rather than those sampled in hospite, as their physiology is likely to be different outside the host (Gates et al. 1995). The nature of the treatments-rapid heating in the previous study versus a $1{ }^{\circ} \mathrm{C} \mathrm{d}^{-1}$ rate here-may also have denote significant differences relative to controls at each time point. (RMANOVA, pairwise post hoc with Bonferroni correction, $n=5$ independent colonies per time point except A. millepora after $7 \mathrm{~d}$ at $33{ }^{\circ} \mathrm{C}$ where $n=4, * P<0.05, * * P<0.01$, ***P $\left.<0.001\right)$. Note the different $y$-axis scales in $\mathbf{a}-\mathbf{c}$

contributed, as could sub-cladal differences in symbiont physiology. However, our data support the hypothesis that symbiont NO synthesis may contribute to their in situ degradation during thermal stress (Hawkins and Davy 2012). Its influence on the eventual intensity of bleaching is less clear, however, and might depend on the time at which host cellular pathways are activated (Hawkins et al. 2013). In any case, further methodological advances would 
be invaluable for investigating Symbiodinium NO synthesis and may confirm the extent to which this phenomenon can affect the bleaching responses of reef corals.

\section{Cellular events in the coral host}

Our findings support the hypothesis that host NO synthesis is involved in coral bleaching (Perez and Weis 2006; Weis 2008), but suggest that the situation in reef corals may be much more complex than in laboratory model systems. For example, host tissue $\mathrm{NO}_{2}{ }^{-}$content-which responds to temperature in Aiptasia pulchella (Detournay and Weis 2011)_changed little in the species examined here. Only when total oxidised $\mathrm{NO}\left(\mathrm{NO}_{\mathrm{x}}{ }^{-}\right)$was quantified did responses become apparent. This was most obvious in $A$. millepora and less so in P. damicornis. M. digitata, the only species of the three not to bleach, showed little evidence of temperature-induced $\mathrm{NO}_{\mathrm{x}}{ }^{-}$accumulation. While it must be acknowledged that there are multiple sources of dissolved inorganic nitrogen in the coral-dinoflagellate association, the interspecific differences in $\mathrm{NO}_{\mathrm{x}}{ }^{-}$and the strong positive effect of the NO donor SNP (ESM Fig. S3) support the suitability of this parameter for assessing tissue NO synthesis.

The corals in this study displayed a range of stress responses, from the limited reaction of $M$. digitata, to the classic photoinhibition/bleaching of $A$. millepora, to the rapid host mortality of $P$. damicornis at $33{ }^{\circ} \mathrm{C}$. The time at which some of the interspecific differences became apparent is of particular interest, and the early nature of host $\mathrm{NO}_{\mathrm{x}}{ }^{-}$accumulation and apoptotic events in $A$. millepora, specifically, raises questions about the importance of symbiont photophysiological dysfunction in initiating the bleaching cascade. The leakage of ROS from compromised symbionts is thought to be a primary mechanism by which symbiont dysfunction stimulates bleaching (Lesser 2006; Tchernov et al. 2011), and our observation of apparent host apoptosis following declining $F_{\mathrm{v}} / F_{\mathrm{m}}$ in $A$. millepora is consistent with this model. However, the level of photosynthetic dysfunction necessary to elicit oxidative stress in Symbiodinium remains unclear, and the evidence for in hospite ROS leakage from symbionts is limited. Most studies that have observed ROS generation/leakage in Symbiodinium employed light-stresses (e.g., Lesser 1996; Suggett et al. 2008; Saragosti et al. 2010) or rapid heatshock treatments (McGinty et al. 2012) significantly more intense than those used here. For example, the temperatureinduced ROS production reported by Suggett et al. (2008) required an irradiance of $1,000 \mu \mathrm{mol}$ photons $\mathrm{m}^{-2} \mathrm{~s}^{-1}$ and occurred when $F_{\mathrm{v}} / F_{\mathrm{m}}$ had declined to $<30 \%$ of control levels. In our study, host apoptotic events in A. millepora (on Day 5) occurred at with symbiont $F_{\mathrm{v}} / F_{\mathrm{m}}>90 \%$ of control values. Tchernov et al. (2011) observed that ROS generation was heightened in heat-stressed coral fragments containing symbionts, relative to pre-bleached specimens, and therefore proposed the symbiont as the source of the ROS. However, host ROS production as a response to the presence of symbionts could have produced the same result. Given the early nature of host responses in this study, and the limited empirical support for the symbiont ROS-leakage hypothesis, we propose that our observations may result from stimuli other than symbiont-derived ROS.

Our data support the hypothesis that host-derived NOperhaps alongside any ROS present in the system-could play a role in the responses of reef corals to thermal stress (Perez and Weis 2006). The transient increase in $\mathrm{NO}_{\mathrm{x}}{ }^{-}$ content of $A$. millepora host tissue correlated with increasing activity of enzymes associated with apoptotic cell death, and NO (especially in the presence of ROS) is known to influence apoptosis by interacting with components of the mitochondrial apoptosis pathway (Wink and Mitchell 1998; Hawkins et al. 2013). A rapid increase in host-derived NO could also adversely affect symbiont physiology (Hawkins and Davy 2012). However, the situation appears to be different in $P$. damicornis, where timing of apparent host $\mathrm{NO}$ synthesis $\left(\mathrm{NO}_{\mathrm{x}}{ }^{-}\right.$accumulation) and declining symbiont $F_{\mathrm{v}} / F_{\mathrm{m}}$ did not correlate with host caspase-like enzyme activation. This suggests that alternative apoptotic pathways (perhaps less dependent on NO) exist in $P$. damicornis, but with little known about the regulation of cell death in scleractinians it is difficult to make specific hypotheses at this stage.

What is clear, however, is that the activity of apoptotic pathways varied significantly between coral species, and this supports a recent hypothesis that differential regulation of apoptosis may be a mechanism by which corals modify their responses to thermal stress (Tchernov et al. 2011). Host caspase-like enzyme activities in the bleachingresistant $M$. digitata showed no response to temperature, and closer examination found that caspase inhibitors had no effect on the rates of substrate cleavage by $M$. digitata homogenates. This either indicates that caspase-like enzyme activity is almost non-existent in this species or it suggests that the enzymes that are present are so dissimilar to those in A. millepora or $P$. damicornis that they are unable to cleave the same substrate. The latter is highly improbable, as DEVDase activity has been successfully quantified in Hydra (Lasi et al. 2010), unicellular chlorophyte algae (Jimenez et al. 2009), and sponges (Wiens et al. 2003). We can therefore conclude that baseline caspase-like enzyme activity in $M$. digitata is negligible. By contrast, the two bleaching-susceptible species both displayed evidence of baseline caspase-like enzyme activity which responded to heating. Interestingly, the induction of host apoptotic pathways occurred days before any symbiont loss became apparent. Maybe this reflects a disruption 


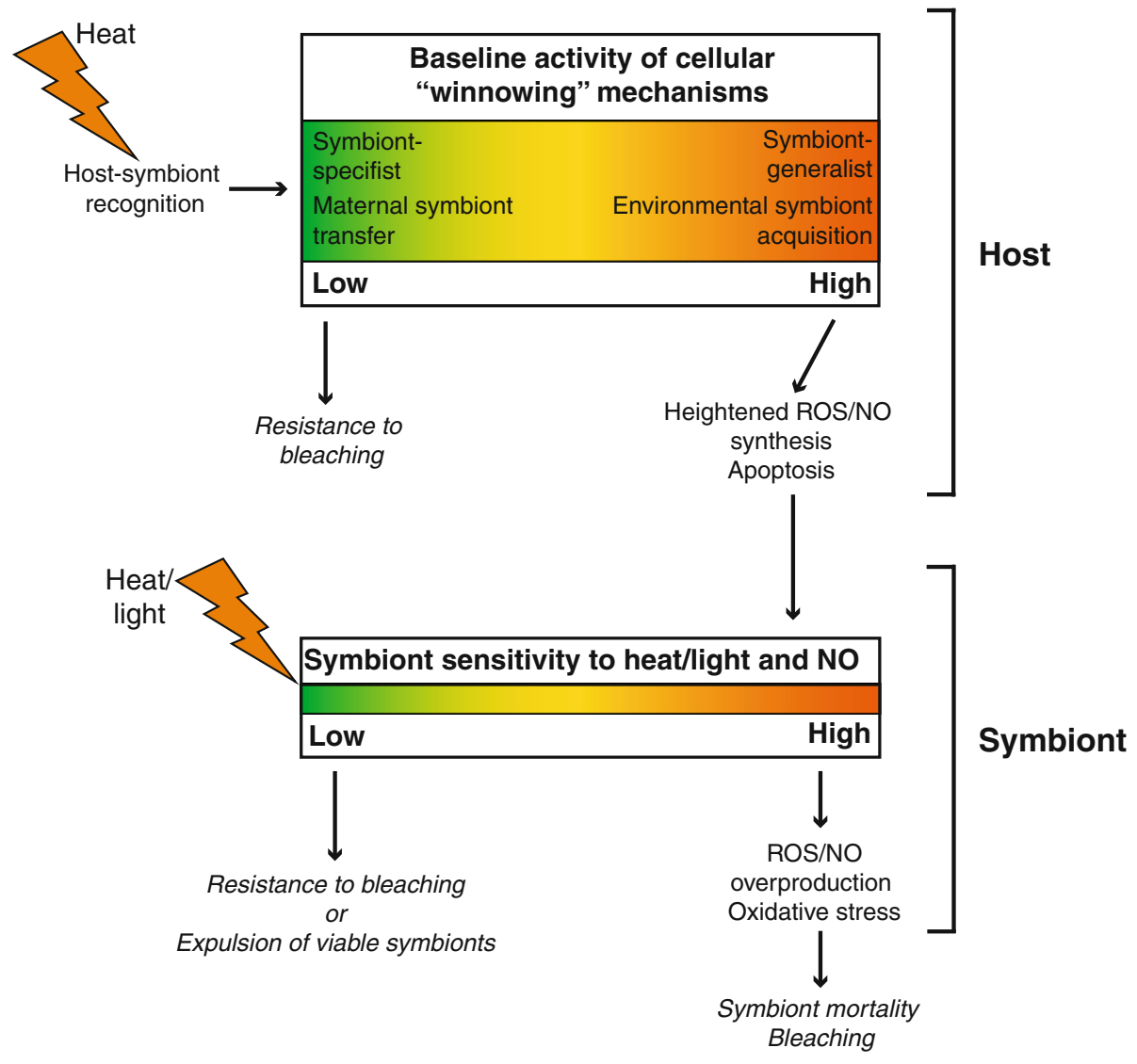

Fig. 3 Hypothetical model of differential bleaching susceptibility in reef corals, incorporating aspects of host-symbiont specificity and symbiont acquisition strategies at a cellular level. The presence of potentially temperature-sensitive "winnowing" pathways-beneficial for the regulation of genetically diverse in hospite symbiont populations-may increase the susceptibility of a coral species to thermal bleaching. Temperature-induced dysfunction of host-

of host-symbiont recognition pathways prior to symbiont degradation and bleaching (see Vidal-Dupiol et al. 2009 for examples). Further work is needed to fill in these gaps in our knowledge. While we cannot entirely discount symbiont-derived ROS as a stimulus for the host responses observed here, our data support a growing body of work suggesting that host-level mechanisms play an important role in determining the bleaching responses of corals (Nii and Muscatine 1997; Fitt et al. 2009; Palmer et al. 2010; Dunn et al. 2012; Paxton et al. 2013; Tolleter et al. 2013).

Towards a cellular basis for differential coral bleaching

To incorporate phenomena such as host NO synthesis and apoptosis into a discussion of differential bleaching susceptibility, one must also acknowledge their non-bleaching functions. As mentioned above, one such function (highly conserved in metazoans) is as a host response to infection (Fang 2004; Carmen and Sinai 2007; Wang and Ruby 2011). symbiont recognition mechanisms (see Vidal-Dupiol et al. 2009) might stimulate host-level "winnowing"-like responses such as nitric oxide (NO) synthesis and apoptosis. These responses, coupled with symbiont sensitivity to heat/light (Fisher et al. 2012), NO (Hawkins and Davy 2012) and oxidative stress (McGinty et al. 2012), could affect the bleaching outcomes (italicised in the figure) of a thermally challenged coral

Successful infection of A. pallida with homologous Symbiodinium (occurring naturally with that host) results in a downregulation of host NO synthesis (Detournay et al. 2012), and the selective removal of unsuitable symbionts ("winnowing") in Fungia scutaria larvae involves an apoptotic-like mechanism (Dunn and Weis 2009). These pathways, presumably advantageous for hosts that associate with multiple symbiont types (and must, therefore, "winnow"/regulate their intracellular symbiont population), appear highly sensitive to temperature (Perez and Weis 2006; Detournay and Weis 2011; Hawkins et al. 2013), and could potentially be disadvantageous during thermal stress. Many of the most bleaching-susceptible corals, including A. millepora and $P$. damicornis, associate with a wide range of symbiont types (Baird et al. 2009; Guest et al. 2012; Putnam et al. 2012) and, furthermore, $A$. millepora acquires its symbionts from the external environment (Baird et al. 2009). These species could benefit from a symbiosis "winnowing" mechanism. Indeed, the 
dominant symbiont genotype in A. millepora on the northern GBR differs between larval and adult life stages (Cumbo et al. 2013), and expression of genes with potential "winnowing" roles has been observed in this species (Puill-Stephan et al. 2012). A heightened baseline activity of such pathways might leave symbiont-generalist corals such as A. millepora and $P$. damicornis more susceptible to bleaching (Fig. 3). Conversely, a species such as $M$. digitata that associates with very few symbiont types and relies solely on maternal symbiont transmission (Baird et al. 2009) would less frequently encounter (on a cellular level, at least) infective symbionts and would presumably receive little adaptive benefit from a "winnowing" mechanism. In concert with the physiological robustness of a C15-type symbiont (Fisher et al. 2012), the relative absence of these "winnowing" pathways could render $M$. digitata more resistant to thermal bleaching (Fig. 3).

This model is speculative, of course, but it does represent a testable hypothesis. To our knowledge, this study provides some of the first physiological data to support the findings of recent meta-analyses of coral-dinoflagellate associations and their susceptibilities to bleaching (Putnam et al. 2012). Further assessments of baseline NO-synthase/ caspase activity and cell-cell recognition pathways in different coral-dinoflagellate associations-characterised by differing symbiont transmission modes and host-symbiont specificities-would be highly instructive. It is clear that the cellular responses of corals to elevated temperature are highly diverse. Elucidating the mechanisms underpinning this diversity is now a major challenge, especially given the environmental changes predicted for the coming century.

Acknowledgments The authors wish to thank the staff at Heron Island Research Station, University of Queensland. We also thank Dr. Olga Pantos for assistance with storage and transportation of coral samples, and the Davy Lab and two anonymous reviewers for commenting on the manuscript. This work was supported by a Marsden Fund grant (contract number VUW0902) awarded to SKD and PLF, and JL Stewart and Faculty of Science Strategic Research Grants awarded to TDH. This work fulfils part of the requirements for a $\mathrm{PhD}$ funded by a Commonwealth Scholarship awarded to TDH.

\section{References}

Baird AH, Bhagooli R, Ralph PJ, Takahashi S (2008) Coral bleaching: the role of the host. Trends Ecol Evol 24:16-20

Baird AH, Guest JR, Willis BL (2009) Systematic and biogeographical patterns in the reproductive biology of scleractinian corals. Annual Review of Ecology, Evolution and Systematics 40:551-571

Baker AC (2001) Ecosystems-Reef corals bleach to survive change. Nature 411:765-766

Berkelmans R, van Oppen MJH (2006) The role of zooxanthellae in the thermal tolerance of corals: A 'nugget of hope' for coral reefs in an era of climate change. Proc R Soc B 273:2305-2312
Bouchard JN, Yamasaki H (2008) Heat stress stimulates nitric oxide production in Symbiodinium microadriaticum: A possible linkage between nitric oxide and the coral bleaching bleaching phenomenon. Plant Cell Physiol 49:641-652

Bradford MM (1976) A rapid and sensitive method for the quantitation of microgram quantities of protein using the principle of protein dye-binding. Anal Biochem 72:248-254

Bryan NS, Grisham MB (2007) Methods to detect nitric oxide and its metabolites in biological samples. Free Radic Biol Med 43:645-657

Buddemeier RW, Fautin DG (1993) Coral bleaching as an adaptive mechanism: a testable hypothesis. Bioscience 43:320-326

Carmen JC, Sinai AP (2007) Suicide prevention: Disruption of apoptotic pathways by protozoan parasites. Mol Microbiol 64:904-916

Cumbo VR, Baird AH, van Oppen MJH (2013) The promiscuous larvae: flexibility in the establishment of symbiosis in corals. Coral Reefs 32:111-120

Detournay O, Weis VM (2011) Role of the sphingosine rheostat in the regulation of cnidarian-dinoflagellate symbioses. Biol Bull 221:261-269

Detournay O, Schnitzler CE, Poole A, Weis VM (2012) Regulation of cnidarian-dinoflagellate mutualisms: Evidence that activation of a host TGFbeta innate immune pathway promotes tolerance of the symbiont. Dev Comp Immunol 38:525-537

Downs CA, Fauth JE, Halas JC, Dustan P, Bemiss J, Woodley CM (2002) Oxidative stress and seasonal coral bleaching. Free Radic Biol Med 33:533-543

Dunn SR, Weis VM (2009) Apoptosis as a post-phagocytic winnowing mechanism in a coral-dinoflagellate mutualism. Environ Microbiol 11:268-276

Dunn SR, Thomason JC, Le Tissier MDA, Bythell JC (2004) Heat stress induces different forms of cell death in sea anemones and their endosymbiotic algae depending on temperature and duration. Cell Death Differ 11:1213-1222

Dunn SR, Pernice M, Green K, Hoegh-Guldberg O, Dove SG (2012) Thermal stress promotes host mitochondrial degradation in symbiotic cnidarians: Are the batteries of the reef going to run out? PLoS ONE 7:e39024

Fang FC (2004) Antimicrobial reactive oxygen and nitrogen species: Concepts and controversies. Nature Rev Microbiol 2:820-832

Fisher PL, Malme MK, Dove S (2012) The effect of temperature stress on coral-Symbiodinium associations containing distinct symbiont types. Coral Reefs 31:473-485

Fitt WK, Gates RD, Hoegh-Guldberg O, Bythell JC, Jatkar A, Grottoli AG, Gomez M, Fisher P, Lajuenesse TC, Pantos O, Iglesias-Prieto R, Franklin DJ, Rodrigues LJ, Torregiani JM, Woesik Rv, Lesser MP (2009) Response of two species of IndoPacific corals, Porites cylindrica and Stylophora pistillata, to short-term thermal stress: The host does matter in determining the tolerance of corals to bleaching. J Exp Mar Biol Ecol 373:102-110

Franklin EC, Stat M, Pochon X, Putnam HM, Gates RD (2012) GeoSymbio: A hybrid, cloud-based web application of global geospatial bioinformatics and ecoinformatics for Symbiodiniumhost symbioses. Mol Ecol Resour 12:369-373

Gates RD, Baghdasarian G, Muscatine L (1992) Temperature stress causes host cell detachment in symbiotic cnidarians: Implications for coral bleaching. Biol Bull 182:324-332

Gates RD, Hoegh-Guldberg O, McFall-Ngai MJ, Bil KY, Muscatine L (1995) Free amino acids exhibit anthozoan "host factor" activity: they induce the release of photosynthate from symbiotic dinoflagellates in vitro. Proc Natl Acad Sci USA 92:7430-7434

Goreau TF, MacFarlane AH (1990) Reduced growth in Montastrea annularis during the 1997-1998 coral bleaching event. Coral Reefs 8:211-215 
Guest JR, Baird AH, Maynard JA, Muttaqin E, Edwards AJ, Campbell SJ, Yewdall K, Affendi YA, Chou LM (2012) Contrasting patterns of coral bleaching susceptibility in 2010 suggest an adaptive response to thermal stress. PLoS ONE 7:e33353

Hawkins TD, Davy SK (2012) Nitric oxide production and tolerance differ among Symbiodinium types exposed to heat stress. Plant Cell Physiol 53:1889-1898

Hawkins TD, Bradley BJ, Davy SK (2013) Nitric oxide mediates coral bleaching through an apoptotic-like cell death pathway: evidence from a model cnidarian-dinoflagellate symbiosis. FASEB J In Press [10.1096/fj.13-235051]

Hill R, Ralph PJ (2007) Post-bleaching viability of expelled zooxanthellae from the scleractinian coral Pocillopora damicornis. Mar Ecol Prog Ser 352:137-144

Hoegh-Guldberg O (1999) Climate change, coral bleaching and the future of the world's coral reefs. Mar Freshw Res 50:839-866

Jimenez C, Capasso JM, Edelstein CL, Rivard CJ, Lucia S, Breusegem S, Berl T, Segovia M (2009) Different ways to die: cell death modes of the unicellular chlorophyte Dunaliella viridis exposed to various environmental stresses are mediated by the caspase-like activity DEVDase. J Exp Bot 60:815-828

Jones RJ (2008) Coral bleaching, bleaching-induced mortality, and the adaptive significance of the bleaching response. Mar Biol 154:65-80

Jones RJ, Hoegh-Guldberg O, Larkum AWD, Schreiber U (1998) Temperature-induced bleaching of corals begins with impairment of the $\mathrm{CO}_{2}$ fixation mechanism in zooxanthellae. Plant Cell Environ 21:1219-1230

Kerr JFR, Whyllie AH, Currie AR (1972) Apoptosis: A basic biological phenomenon with wide ranging implications in tissue kinetics. Br J Cancer 26:239-257

LaJeunesse TC (2002) Diversity and community structure of symbiotic dinoflagellates from Caribbean coral reefs. Mar Biol 141:387-400

Lasi M, Pauly B, Schmidt N, Cikala M, Stiening B, Kasbauer T, Zenner G, Popp T, Wagner A, Knapp RT, Huber AH, Grunert M, Soding J, David CN, Bottger A (2010) The molecular cell death machinery in the simply cnidarian Hydra includes an expanded caspase family and pro- and anti-apoptotic Bcl-2 proteins. Cell Res 1:1-14

Lesser MP (1996) Elevated temperatures and ultraviolet radiation cause oxidative stress and inhibit photosynthesis in symbiotic dinoflagellates. Limnol Oceanogr 41:271-283

Lesser MP (2006) Oxidative stress in marine environments. Annu Rev Physiol 68:253-278

Logan DDK, LaFlamme AC, Weis VM, Davy SK (2010) Flowcytometric characterization of the cell-surface glycans of symbiotic dinoflagellates (Symbiodinium spp.). J Phycol 46:525-533

McGinty ES, Pieczonka J, Mydlarz LD (2012) Variations in reactive oxygen release and antioxidant activity in multiple Symbiodinium types in response to elevated temperature. Microb Ecol 64:1000-1007

Miranda KM, Espey MG, Wink DA (2001) A rapid, simple spectrophotometric method for simultaneous detection of nitrate and nitrite. Nitric Oxide 5:62-71

Muscatine L, Porter JW (1977) Reef corals: mutualistic symbioses adapted to nutrient-poor environments. Bioscience 27:454-460

Mydlarz LD, McGinty ES, Harvell CD (2010) What are the physiological and immunological responses of coral to climate warming and disease? J Exp Biol 213:934-945

Nii CM, Muscatine L (1997) Oxidative stress in the symbiotic sea anemone Aiptasia pulchella (Carlgren, 1943): Contribution of the animal to superoxide ion production at elevated temperature. Biol Bull 192:444-456

Nussler AK, Glanemann M, Schirmeier A, Liu L, Nuessler NC (2006) Fluorometric measurement of nitrite/nitrate by 2,3-diaminonaphthalene. Nature Protocols 1:2223-2226
Palmer CV, Bythell JC, Willis BL (2010) Levels of immunity parameters underpin bleaching and disease susceptibility of reef corals. FASEB J 24:1935-1946

Paxton CW, Davy SK, Weis VM (2013) Stress and death of host cells play a role in cnidarian bleaching. J Exp Biol 216:2813-2820

Perez SF (2007) Exploring the cellular mechanisms of cnidarian bleaching in the sea anemone Aiptasia pallida. PhD Thesis, Oregon State University

Perez S, Weis VM (2006) Nitric oxide and cnidarian bleaching: An eviction notice mediates breakdown of a symbiosis. J Exp Biol 209:2804-2810

Pernice M, Dunn SR, Miard T, Dufour S, Dove S, Hoegh-Guldberg O (2011) Regulation of apoptotic mediators reveals dynamic responses to thermal stress in the reef building coral Acropora millepora. PLoS ONE 6:e16095

Pochon X, Montoya-Burgos JI, Stadelmann B, Pawlowski J (2006) Molecular phylogeny, evolutionary rates, and divergence timing of the symbiotic dinoflagellate genus Symbiodinium. Mol Phylogenet Evol 38:20-30

Porra R, Thompson W, Kriedemann P (1989) Determination of accurate extinction coefficients and simultaneous equations for assaying chlorophylls $a$ and $b$ extracted with four different solvents: Verification of the concentration of chlorophyll standards by atomic absorption spectroscopy. Biochim Biophys Acta-Bioenergetics 975:384-394

Pratchett MS, Wilson SK, Graham NA, Munday PL, Jones GP, Polunin NVC (2009) Coral bleaching and consequences for motile reef organisms: Past, present and uncertain future effects. In: van Oppen MJ, Lough JM (eds) Coral bleaching: Patterns, processes, causes and consequences. Springer-Verlag, Heidelberg, Germany, pp 139-152

Puill-Stephan E, Seneca FO, Miller DJ, van Oppen MJH, Willis BL (2012) Expression of putative immune response genes during early ontogeny in the coral Acropora millepora. PLoS ONE 7:e39099

Putnam HM, Stat M, Pochon X, Gates RD (2012) Endosymbiotic flexibility associates with environmental sensitivity in scleractinian corals. Proc R Soc B 279:4352-4361

Ralph PJ, Gademann R, Larkum AWD (2001) Zooxanthellae expelled from bleached corals at $33^{\circ} \mathrm{C}$ are photosynthetically competent. Mar Ecol Prog Ser 220

Rowan R, Knowlton N, Baker A, Jara J (1997) Landscape ecology of algal symbionts creates variation in episodes of coral bleaching. Nature 388:265-269

Sampayo EM, Ridgway T, Bongaerts P, Hoegh-Guldberg O (2008) Bleaching susceptibility and mortality of corals are determined by fine-scale differences in symbiont type. Proc Nat Acad Sci USA 105:10444-10449

Saragosti E, Tchernov D, Katsir A, Shaked Y (2010) Extracellular production and degradation of superoxide in the coral Stylophora pistillata and cultured Symbiodinium. PLoS ONE 5:e12508

Stimson J, Kinzie RA (1991) The temporal pattern and rate of release of zooxanthellae from the reef coral Pocillopora damicornis (Linneaus) under nitrogen-enrichment and control conditions. J Exp Mar Biol Ecol 153:63-74

Suggett DJ, Warner ME, Smith DJ, Davey P, Hennige S, Baker NR (2008) Photosynthesis and production of hydrogen peroxide by Symbiodinium (Pyrrhophyta) phylotypes with different thermal tolerances. J Phycol 44:948-956

Tchernov D, Kvitt H, Haramaty L, Bibby TS, Gorbunov MY, Rosenfeld H, Falkowski PG (2011) Apoptosis and the selective survival of host animals following thermal bleaching in zooxanthellate corals. Proc Nat Acad Sci USA 108:9905-9909

Tolleter D, Seneca François O, DeNofrio Jan C, Krediet Cory J, Palumbi Stephen R, Pringle John R, Grossman Arthur R (2013) Coral bleaching independent of photosynthetic activity. Curr Biol 23:1782-1786 
Trapido-Rosenthal HG, Sharp KH, Galloway TS, Morrall CE (2001) Nitric oxide and cnidarian-dinoflagellate symbioses: Pieces of a puzzle. Am Zool 41:247-257

van Hooidonk R, Maynard JA, Planes S (2013) Temporary refugia for coral reefs in a warming world. Nature Climate Change 3:508-511

Vidal-Dupiol J, Adjeroud M, Roger E, Foure L, Duval D, Mone Y, Ferrier-Pages C, Tambutte E, Tambutte S, Zoccola D, Allemand D, Mitta G (2009) Coral bleaching under thermal stress: Putative involvement of host/symbiont recognition mechanisms. BMC Physiol 9:14

Wang YL, Ruby EG (2011) The roles of NO in microbial symbioses. Cell Microbiol 13:518-526

Warner ME, Fitt WK, Schmidt GW (1999) Damage to photosystem II in symbiotic dinoflagellates: A determinant of coral bleaching. Proc Natl Acad Sci USA 96:8007-8012
Weis VM (2008) Cellular mechanisms of cnidarian bleaching: Stress causes the collapse of symbiosis. J Exp Biol 211:3059-3066

Weis VM (2010) The susceptibility and resilience of corals to thermal stress: Adaptation, acclimatization or both? Mol Ecol 19:1515-1517

Wiens M, Krasko A, Perovic S, Muller WEG (2003) Caspasemediated apoptosis in sponges: Cloning and function of the phylogenetic oldest apoptotic proteases from metazoa. Biochim Biophys Acta-Mol Cell Res 1593:179-189

Wink DA, Mitchell JB (1998) Chemical biology of nitric oxide: Insights into regulatory, cytotoxic, and cytoprotective mechanisms of nitric oxide. Free Radic Biol Med 25:434-456 